\title{
Characterization and Management of Fungal Deterioration of Ancient Limestone at Different Sites Along Egypt
}

\author{
Samar S. Mohamed ${ }^{(1) \#}$ and Soha Eid Ibrahim ${ }^{(2)}$ \\ ${ }^{(1)}$ Microbiology Department, Faculty of Science, Ain Shams University, Cairo, \\ Egypt; ${ }^{(2)}$ Center of Research and Conservation of Antiquities, Ministry of Antiquities, \\ Cairo, Egypt.
}

\begin{abstract}
$\mathbf{F}$ UNGI play a very treacherous role in the biodeterioration of stone monuments, leading to their loss. In order to preserve these monuments, the incidence and the biodeterioration effect of fungi on ancient limestone monuments at different Egyptian sites were evaluated. Specimens as well as swabs were collected from different Egyptian sites including, Seti I tomb at Luxor, Senusret I obelisk of Al Mattaryia district, Giza pyramid complex and related tomb, storehouse of National Museum of Egyptian Civilization (NMEC), Mosque of Judge Abd El Basset (Gamaliya), Roman Amphitheatre of Alexandria and Ismailia Museum of Antiquities. Seti I tomb, Mosque of judge Abd El basset and Senusret I obelisk were the most sites occupied by fungi, while Giza pyramid complex and Museum of Ismailia Antiquities were the lowest ones. Aspergillus niger and A. terreus were the most common and dominant fungal deteriogens of all archaeological sites, followed by Cladosporium cladosporidis, C. hebarum and $A$. fumigatus. Cladosporium herbarum showed the highest stone dissolution value, $23.3 \%$, followed by $A$. terreus and $A$. niger ( $21.7 \%$ and $20.7 \%$, respectively). Stone cubes incubated for two months with $C$. herbarum showed different aspects of deterioration including discoloration, dark pigmentation, powdering and dissolution. Also compressive strength and stone porosity were reduced by $27.7 \%$ and $25.7 \%$, respectively. Synthetic antimicrobials; PCMC, certrimonium and TEAB inhibited all stone colonizing fungal isolates at concentrations of $1.25 \mathrm{~g} / \mathrm{L}, 5 \mathrm{~g} / \mathrm{L}$ and $2.5 \mathrm{~g} / \mathrm{L}$, respectively, while natural antimicrobials; cinnamon, thyme and clove oil inhibited fungal isolates at concentrations of $5 \mathrm{~g} / \mathrm{L}, 5 \mathrm{~g} / \mathrm{L}$ and $10 \mathrm{~g} / \mathrm{L}$, respectively.
\end{abstract}

Keywords: Stone monuments, Fungal deterioration, Mineral dissolution, Simulation, Antifungal activity.

\section{Introduction}

Ancient Egypt was regarded as the "state out of stone" because stone was the most important raw material used during the different periods of Pharaonic Egypt until Graeco-Roman and Arab times. Stone buildings located in tropical and sub-tropical regions throughout the world are particularly vulnerable to microbial deterioration; since the prevailing environmental conditions of temperature and humidity are more suitable for microbial growth (Evers, 1929).

Fungi are the most active agents in earth processes that cause the alteration and weathering of rocks (Gadd, 2007). They are found on mural paintings in churches, in caves and in catacombs and even in the architectural surfaces and stone monuments (Ettenauer et al., 2010 and Ma et al., 2015).
Fungi play a very treacherous role in the biodeterioration of stone monuments for their complex metabolic activities on stone surface. Many fungal species, such as Alternaria, Aspergillus, Acremonium, Arthobotrys, Auerobasidium, Cladosporium, Curvularia, Drechslera, Fusarium, Helminthosporium, Mucor, Phoma, Penicillium, Rhizopus and Trichothecium have been isolated from the stone monuments found in different countries. The growth of these fungal genera on stone monuments was the origin of staining and decay of stone material of these monuments (Strzelczyk, 2004 and Dominguez-Moñino et al., 2017).

Fungi produce many inorganic and organic acids on monuments and these acids are the main reason for mineral dissolution and structural change of stone material especially the organic acids, such as oxalic, lactic and gluconic acids,

\#Corresponding author email: samar_samer78@yahoo.com DOI: 10.21608 /ejm.2018.4735.1068

(C)2018 National Information and Documentation Center (NIDOC) 
which are known as chelating agents that can demineralize a variety of stone substrates including calcium, silicon, iron, magnesium and manganese (Juroczkin et al., 1988; Saiz-Jimenez, 1995 and Abd-Elkareem \& Mohamed, 2017) and also give a competitive benefit for filamentous fungi over other microorganisms by declining the environmental pH (Liaud et al., 2014 and Fazio et al., 2015).

Usually, biodeterioration of binding material of stone monuments begins with the dissolution of calcium then the monumental surface erodes and becomes exposed to external environment. Further interaction between fungal hyphae and stone substrate causes the formation of biofilms with different colors and chemical compositions (Garcia-Valles et al., 2000). However, control of fungal growth on the monuments is not easy due to fungal thick, melanized cell walls that resist chemical attack and cannot easily be inhibited by biocides or other anti-microbial treatments (Kordali et al., 2005). Furthermore, the application of synthetic chemical on the monuments as biocides is toxic and unsafe to the environment and to public health (Fortune et al., 2008). Essential oils and their constituents have been extensively used as antimicrobial agents, but little is known about their application on stone preservation.

Because of the historical and economical value of the Egyptian monuments, a lot of effort is being invested in preserving them and preventing their loss. Accordingly, this study aims to evaluate the incidence and the biodeterioration effect of fungi on ancient limestone monuments at different Egyptian sites and examine the ability of some compounds to inhibit the fungal growth without affecting monuments composition.

\section{Materials and Methods}

\section{Study sites}

In this study, fungal contaminants were aseptically collected from seven Egyptian sites including Seti I tomb at Luxor, Senusret I obelisk of Al Mattaryia district, Giza pyramid complex and related tomb, storehouse of National Museum of Egyptian Civilization (NMEC), Mosque of Judge Abd El Basset (Gamaliya), Roman Amphitheatre of Alexandria and Ismailia Museum of Antiquities (Fig. 1).
Sampling, isolation, counting and identification of fungi

Samples were collected by direct swabbing and also by collecting decayed solid samples (Urzi et al., 2003). Swabs were cultured directly on Czapek's dox agar medium, while each $1 \mathrm{~g}$ of solid decayed samples was suspended in $100 \mathrm{ml}$ saline solution and serially diluted for general counting of stone fungal colonizers on Czapek's dox agar (Sarah et al., 2013). The isolates were purified and their macro morphological characteristics were studied onto Czapek's dox agar, potato dextrose agar and malt extract agar. Micro morphological features of taxonomic interest were examined using slide culture technique. The fungal isolates were identified according to De Hoog \& Guarro (1995), Pitt (2000) and Klich (2001).

Qualitative evaluation of stone dissolution by fungal species

The qualitative ability of fungal isolates to secrete acids which is the most common mechanism of microbial deterioration was measured by culturing fungal isolates on Czapek's dox agar medium without sucrose at $5 \% \mathrm{NaCl}$ supplemented with calcium carbonate (calcite) as it is the main constituent of limestone (Paris et al., 1995). This medium is considered selective for only the isolates that can utilize calcium carbonate (biodeteriogen).

\section{Quantitative evaluation of stone dissolution by fungal species}

Fifty ml of Czapek's dox broth supplemented with $1 \mathrm{gm} \mathrm{CaCO}_{3}$ was inoculated by spore suspensions of fungal isolates with a concentration of $1 \times 10^{6} \mathrm{spores} / \mathrm{ml}$ and incubated for 21 days at $28^{\circ} \mathrm{C}$ at $170 \mathrm{rpm}$ in a rotary shaker. The assay was done in triplicate. Following incubation, the broth media were filtered through Whatman filter paper number 1 and the $\mathrm{CaCO}_{3}$ residue was dissolved in $30 \mathrm{ml} \mathrm{HCl}(1 \mathrm{M})$ that dissolved the non-utilized $\mathrm{CaCO}_{3}$ leaving excess $\mathrm{HCl}$ that was titrated against $1 \mathrm{M} \mathrm{NaOH}$ (Scott, 1969).

Biochemical characterization of deteriorative activity of fungal isolates

Melanin and acid production ability of the most deteriorative fungal isolates were examined as two of the main deterioration mechanisms that affect the stone consolidation and aesthetical appearance. Acid and melanin production ability 
of fungal isolates were tested by culturing on glucose bromo cresol agar medium and tyrosine agar medium, respectively (Eisenman \& Casadevall, 2012 and Zarina \& Parwez, 2013).

\section{Simulation of infection}

Limestone cubes of $5 \mathrm{~cm}^{3}$ and $1 \mathrm{~cm}^{3}$ were used as short term stone model in the simulation experiment. They were autoclaved at $121^{\circ} \mathrm{C}$ for $20 \mathrm{~min}$. Artificial infection by the most potent deteriorating isolates; Cladosporium herbarum; was applied. Freshly prepared spore suspension $\left(1 \times 10^{6}\right.$ spores $\left./ \mathrm{ml}\right)$ was spread uniformly on stone surface under aseptic conditions. Sealed container was incubated for a month. Control samples of un-inoculated limestone cubes were also done (Burford et al., 2003). The infected cubes were examined every week for signs of deterioration. After the incubation period some analyses were performed for detection of the fungal deterioration signs:
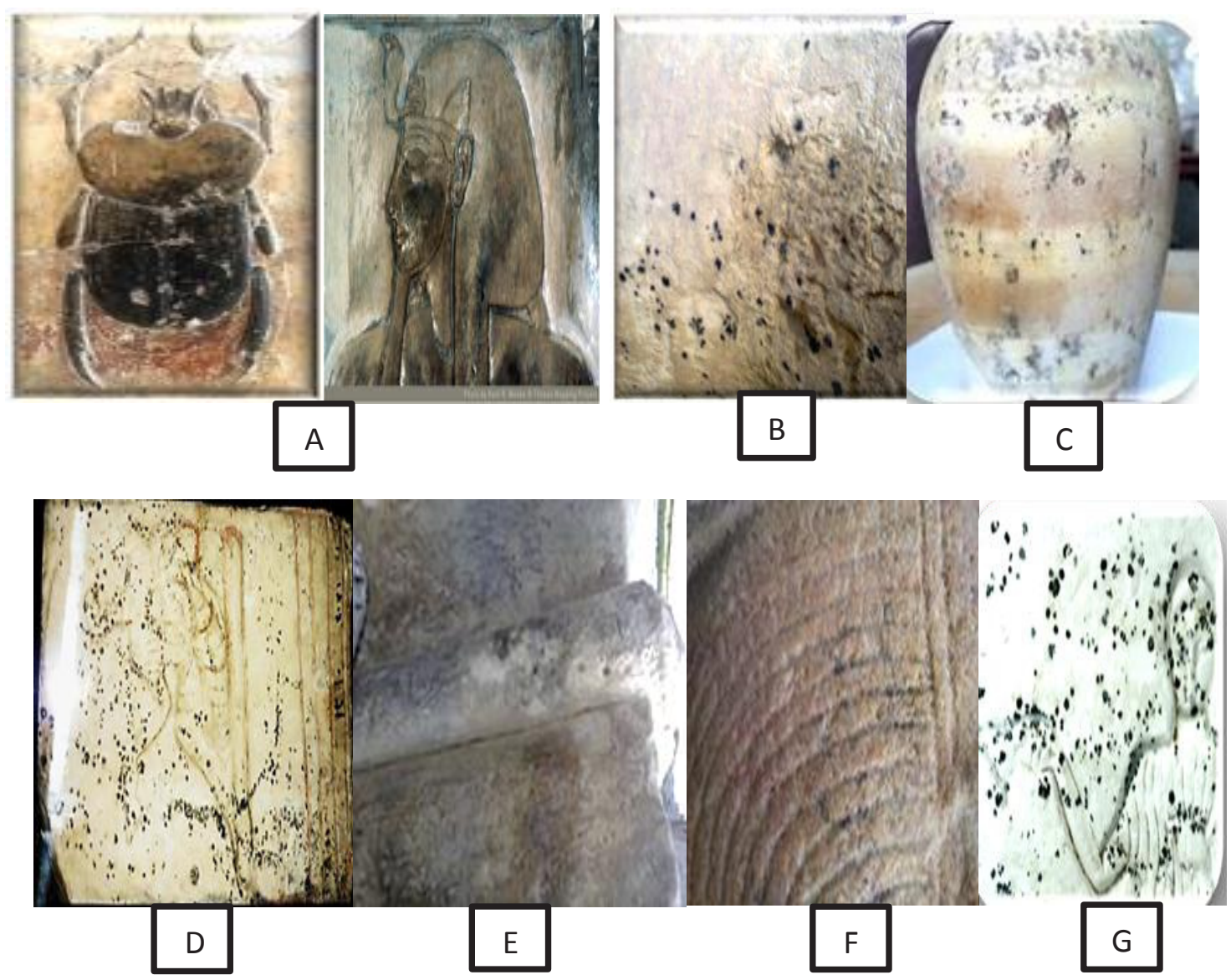

Fig. 1. Stone monuments deteriorated surfaces, (A) Seti tomb at Luxor, (B) Senusret I obelisk, (C) National Museum of Egyptian Civilization storehouse, (D) Giza pyramid complex queen tombs, (E) Mosque of Judge Abd El Basset, (F) Roman Amphitheatre of Alexandria and (G) Museum of Ismailia Antiquities. 
Micrographic examinations

Scanning electron microscope attached Energy Dispersive X-ray Unit (SEM-EDX, JEOL-JSM 5500 LV, Japan) was used to detect morphological changes of artificially infected stones.

Chemical characterization of mineral
constituents
Energy-dispersive X-ray spectroscopy
(EDXS) unit of scanning electron microscope
was applied to determine chemical changes of
artificially infected stones.

\section{Control of stone fungal deteriorative species}

In virto antifungal activity

Fungal species possessing two criteria; the highest potency to dissolute stone material and also predominant in most archeological sites; were selected for the treatment experiment. Two replica of each isolate (containing $10^{6}$ spores/ $\mathrm{ml}$ ) were tested for their susceptibility to both chemical compounds (para, meta chloro cresol, tetra ethyl ammonium bromide and cetrimonium) and natural compounds of essential oil (cinnamon, clove, pepper mint, lavender, camphor and thyme) at different concentrations. Antifungal testing was performed using well diffusion method on Mueller-Hinton agar medium and minimum inhibitory concentration (MIC) was measured in millimeter (Bordoloi et al., 2001 and Mourad et al., 2011).

Simulation of treatment and conservation of Cladosporium herbarum infected limestones

First of all, FTIR analysis was used to evaluate the effect of natural and synthetic antimicrobial agents on stone components. Natural limestone cubes were subjected to the MIC of natural and synthetic antimicrobial agents after sterilization by autoclaving. The measurement was done at spectral range (wavenumber) $4000 \mathrm{~cm}^{-1}-650 \mathrm{~cm}^{-1}$ using Vertex 70 spectrometer at the center of researches and conservation of antiquities (Alakomi et al., 2004).

Five sets of limestone cubes were subjected to the MIC of the most effective compound as a simulation model of both treatment and conservation experiment. Inhibitor treatments were done by soaking.

Simulation of treatment: Three sets of cubes were inoculated with Cladosporium herbarum fungal spore suspension $\left(10^{6}\right.$ spores $\left./ \mathrm{ml}\right)$ and incubated for one month, then one set of the cubes were treated by $0.06 \%$ PCMC (the most potent chemical compound) and the other set was treated by $0.1 \%$ cinnamon (the most potent natural compound) and incubated overnight. The third set was left untreated as a control.

Simulation of conservation: Two sets were treated with the same antifungal agents and incubated overnight, then infected with Cladosporium herbarum and incubated for a month.

Finally, each set was immersed in saline solution, vortexed and cultured using pour plate technique to ensure sterility for counting of grown colonies. The cultured plates were incubated for 7 days at $28^{\circ} \mathrm{C}$ and the colony count was recorded in each case (Bhatnagar \& Jain, 2014).

\section{$\underline{\text { Results }}$}

Total fungal count at surveyed sites

Results showed that Seti I tomb, Mosque of judge Abd El basset and Senusret I obelisk were the most fungal occupied sites $\left(9.5 \times 10^{4} \mathrm{CFU} / \mathrm{g}\right)$, while Giza pyramid complex and Museum of Ismailia Antiquities were the poorest one $\left(2 \times 10^{3} \mathrm{CFU} / \mathrm{g}\right)$ (Table 1$)$. These counts were based on Czapek-Dox agar medium.

\section{Identification of fungal isolates colonizing stone monuments}

Fifteen fungal species belonging to five genera were identified morphologically (Table 2).

Aspergillus niger and $A$. terreus were the most common and dominant fungal deteriogens of stone monuments of all archaeological sites, followed by Cladosporium cladosporioides which was found at $85.7 \%$ of all sites, while $C$. hebarum and A. fumigatus were found at $71.4 \%$ of the archeological sites. Other fungal species showed variations in their occurrence.

\section{Stone dissolution by fungal species}

The highest percentage of calcium carbonatedegrading fungal species were obtained from the Roman Amphitheatre of Alexandria and the Giza pyramid complex (75\% and $63.6 \%$, respectively), while the lowest percentage was obtained from Mosque of Judge Abd El Basset and Senusret I obelisk of Al Matariyyah district (25\% and 29.1\%, respectively) (Table 3 ). 
TABLE 1. Total fungal count by direct swabs and solid decayed samples at the surveyed archeological sites

\begin{tabular}{lcc}
\hline Archeological site & $\begin{array}{c}\text { Mean CFU/g from solid } \\
\text { decayed samples }\end{array}$ & $\begin{array}{c}\text { Mean CFU from pooled } \\
\text { swabs }\end{array}$ \\
\hline Seti I tomb at Luxor & $9 \times 10^{4}$ & 52 \\
Senusret I obelisk & $9.5 \times 10^{4}$ & 34 \\
Giza pyramid complex & $2 \times 10^{3}$ & 15 \\
National Museum of Egyptian Civilization (NMEC) & $6.8 \times 10^{4}$ & 31 \\
storehouse & $9.7 \times 10^{4}$ & 44 \\
Mosque of Judge Abd El Basset & $8.3 \times 10^{3}$ & 19 \\
The Roman Amphitheatre & $5.5 \times 10^{3}$ & 17 \\
Museum of Ismailia Antiquities & & \\
\hline
\end{tabular}

CFU (Colony forming unit)

TABLE 2. Fungal species along different Egyptian archeological sites.

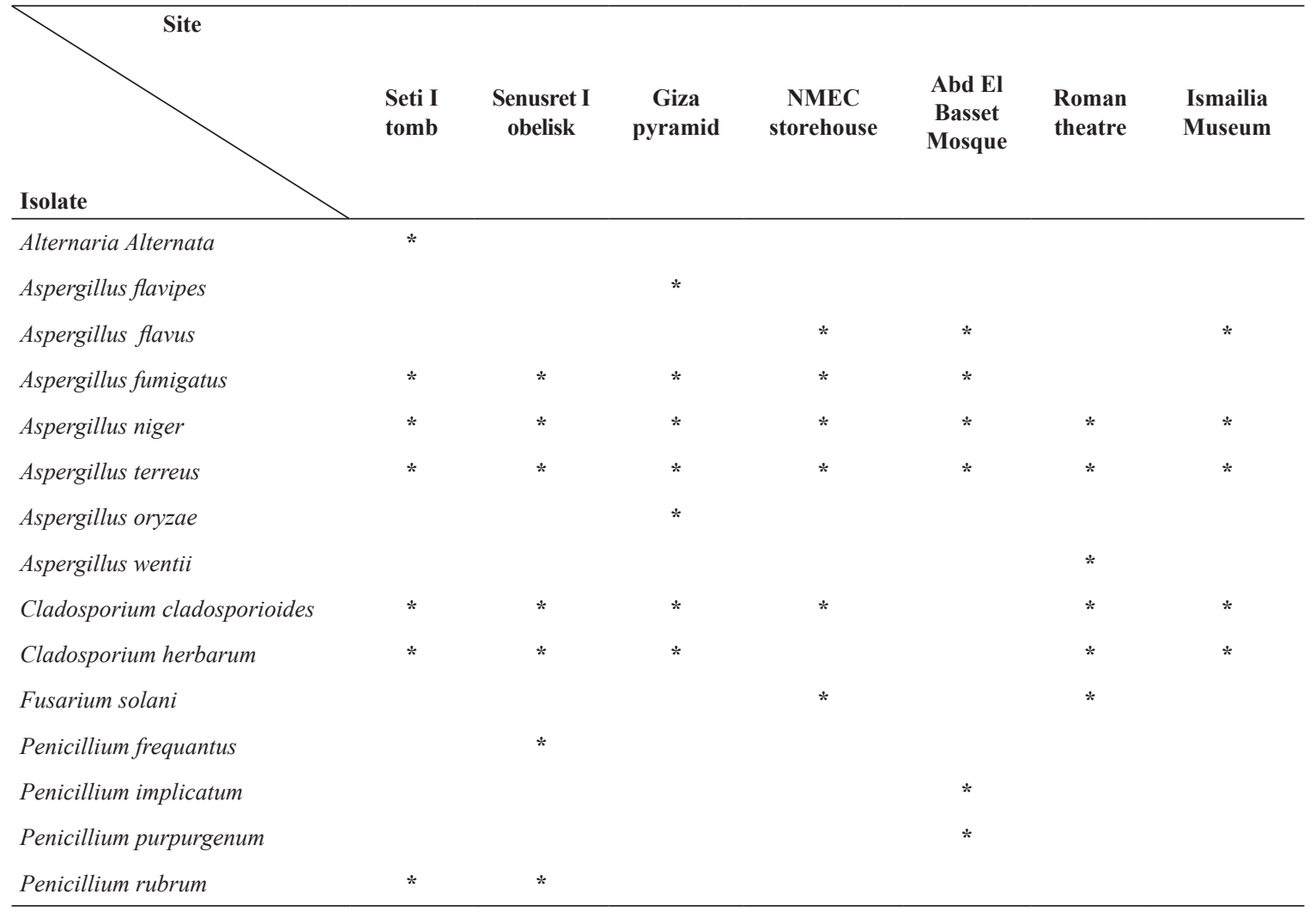

TABLE 3. Percentage of calcium carbonate-degrading fungal species at surveyed sites.

\begin{tabular}{lccc}
\hline Archeological site & $\begin{array}{c}\text { Tested fungal } \\
\text { isolates }\end{array}$ & $\begin{array}{c}\text { Fungal isolates } \\
\text { grown on CaCO }\end{array}$ & $\begin{array}{c}\text { Percentage } \\
(\%)\end{array}$ \\
\hline Seti I tomb at Luxor & 17 & 7 & 41.1 \\
Senusret I obelisk of Al Matariyyah district & 24 & 7 & 29.1 \\
Giza pyramid complex and related tomb & 11 & 7 & 63.6 \\
National Museum of Egyptian Civilization storehouse & 16 & 6 & 37.5 \\
Mosque of Judge Abd El Basset in the region & 24 & 6 & 25 \\
The Roman Amphitheatre of Alexandria & 8 & 5 & 75 \\
Museum of Ismailia Antiquities & 13 & & 38.4 \\
\hline
\end{tabular}


Quantitative evaluation of stone dissolution by fungal species

Fungal isolates varied in their dissolution ability of calcium carbonate, where Cladosporium herbarum showed the highest dissolution value (23.3\%) followed by $A$. terreus and $A$. niger with dissolution values of $21.7 \%$ and $20.7 \%$, respectively. The lowest dissolution values were observed for Penicillium frequantus and Fusarium solani (11.9\% and $12.3 \%$, respectively) (Table 4).

Biochemical characterization of the deteriorative activities of fungal isolates

Concerning acid production, data in Table 5 showed that most of the fungal species were acid producers, while only Alternaria alternata, Aspergillus terreus and Cladosporium herbarum were melanin producers.

\section{Simulation of infection}

After two month incubation period in $C$. herbarium, the stone cubes showed different

aspects of deterioration including discoloration, dark pigmentation, powdering and dissolution at the bottom of the glass container (Fig. 2).

Physical changes of artificially-infected limestone

All physical characteristics of the infected limestone were reduced, where compressive strength and stone porosity of the infected limestone were reduced by $27.7 \%$ and $25.7 \%$, respectively, when compared to control (Table 6).

Morphological changes of artificially-infected
limestone
Different SEM images showed wide range of
deterioration features (Fig. 3). Physical distortion
appeared as void or pits between granules,
while uncolonized limestone (control) exhibited
normal amorphous grains. Also, Fig. 3 showed
that, Cladosporium hebarum mycelium was
distributed around the grains, microbial biofilm and
exopolymeric substances were found as well.

TABLE 4. Quantitative evaluation of stone dissolution by fungal species.

\begin{tabular}{lclc}
\hline Fungal species & $\begin{array}{c}\text { Percentage } \\
\text { of CaCo } \\
\text { dissolution }\end{array}$ & Fungal species & $\begin{array}{c}\text { Percentage } \\
\text { of CaCo } \\
\mathbf{C}_{3} \\
\text { dissolution }\end{array}$ \\
\hline Alternaria alternata & 17 & Cladosporium cladosporioides & 21 \\
Aspergillus flavipes & 16 & Cladosporium herbarum & 23 \\
Aspergillus flavus & 19 & Fusarium solani & 12 \\
Aspergillus fumigatus & 17 & Penicillium frequantus & 12 \\
Aspergillus niger & 21 & Penicillium implicatum & 21 \\
Aspergillus terreus & 22 & Penicillium purpurgenum & 12 \\
Aspergillus oryzae & 15 & Penicillium rubrum \\
Aspergillus wentii & 13 & & \\
\hline
\end{tabular}

TABLE 5. Acid and melanin production ability of fungal isolates.

\begin{tabular}{|c|c|c|}
\hline Fungal species & Acid production & Melanin production \\
\hline Alternaria alternata & + & + \\
\hline Aspergillus flavus & + & - \\
\hline Aspergillus niger & + & - \\
\hline Aspergillus terreus & + & + \\
\hline Cladosporium cladosporioides & + & - \\
\hline Cladosporium herbarum & + & + \\
\hline
\end{tabular}



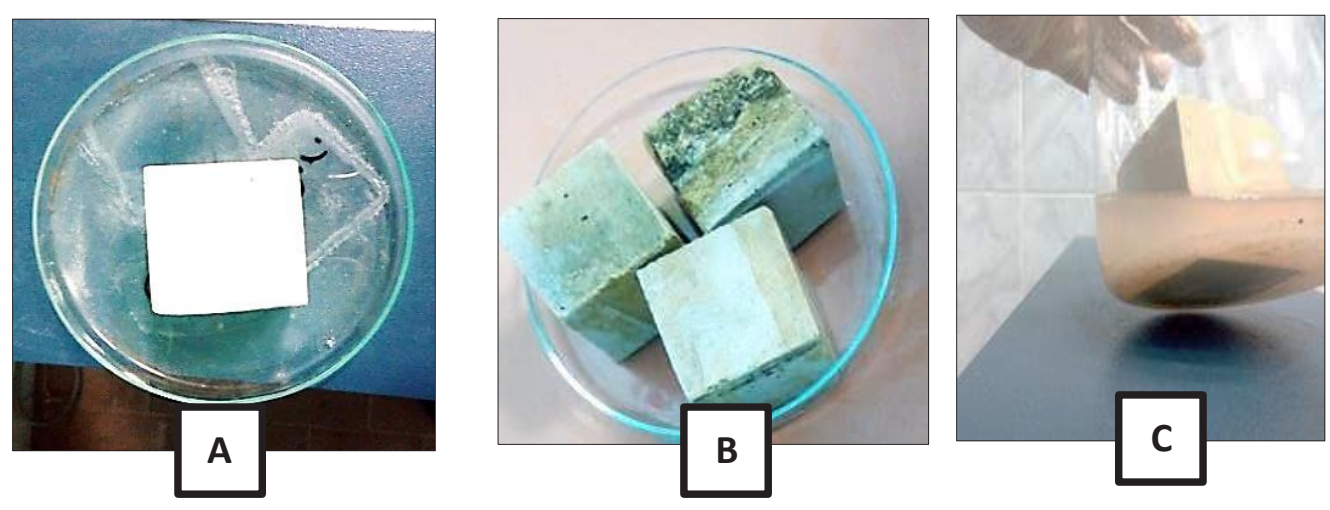

Fig. 2. Visual morphological changes of limestone, (A) Uninfected (control), (B) Three replicas of infected cubes and (C) Stone material disintegration.

TABLE 6. Evaluation of compressive strength and porosity of artificially-infected limestone.

\begin{tabular}{lccc}
\hline Physical character & Control & Inoculated & Reduction percentage (\%) \\
\hline Compressive strength $\left(\mathrm{kg} / \mathrm{cm}^{2}\right)$ & 323.8 & 234.3 & 27.6 \\
$\%$ Porosity & 11 & 8.1 & 26.4 \\
\hline
\end{tabular}
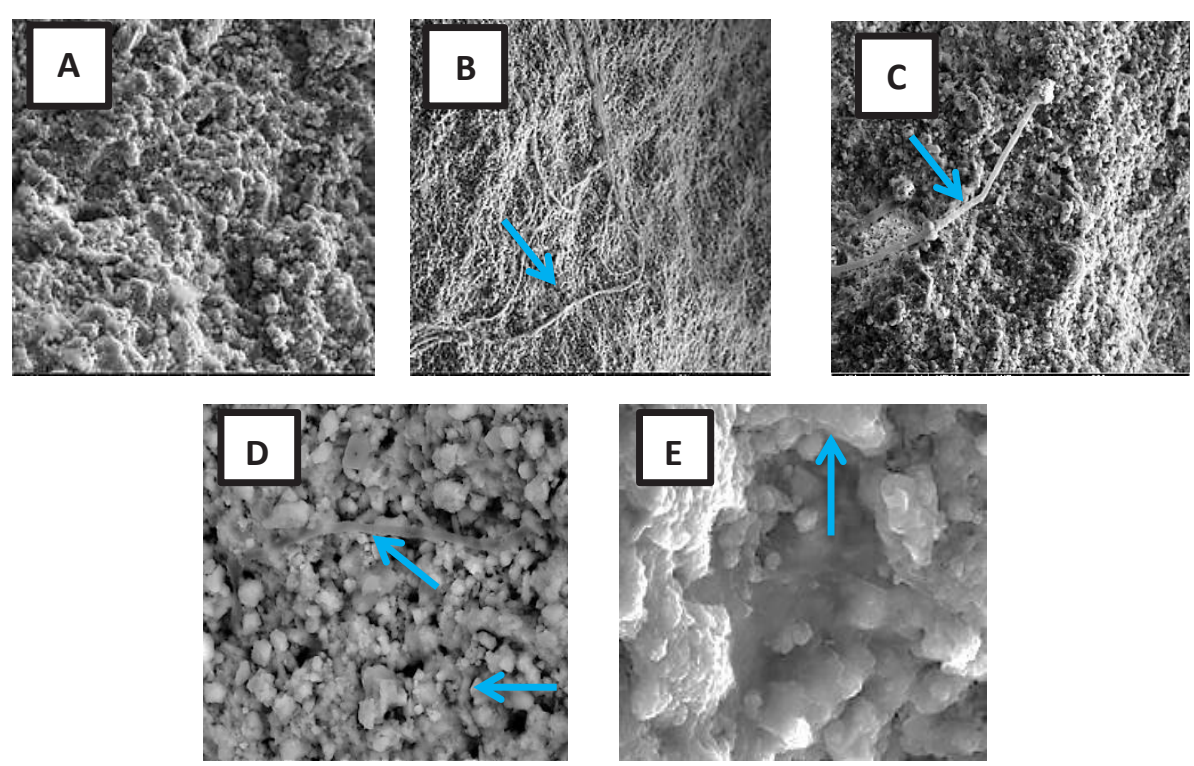

Fig. 3. Morphological changes within control and inoculated limestone samples using SEM. (A) uncolonized limestone, (B), (C) and (D) Represent fungal hyphae within limestone granules and (E) Represents fungal biofilm and exopolymeric substances. (Arrows point to fungal hyphae.)

\section{Chemical changes of artificially-infected limestone}

Figure 4 of the Energy-dispersive X-ray spectroscopy (EDXS) microanalysis of various samples showed that, the control samples essentially consist of calcium $(\mathrm{Ca})$, silicon $(\mathrm{Si})$, aluminum (Al), (C) carbon and (O) oxygen. Calcium as a main source of limestone samples was decreased in all fungus-infected cubes, whereas oxygen increased and also new salts were formed including sodium $(\mathrm{Na})$, chloride $(\mathrm{Cl})$, iron $(\mathrm{Fe})$ and sulfur $(\mathrm{S})$.

\section{Control of stone deteriorative fungal species} In virto antifungal activity

Results of Table 7 revealed that there was considerable variability in the size of inhibition zone among different chemical and natural compounds. The minimum inhibitory concentration of para, meta chloro cresol (PCMC) was $1.25 \mathrm{~g} / \mathrm{L}$ for all tested fungal species and $0.6 \mathrm{~g} / \mathrm{L}$ for $66.6 \%$ of tested isolates, where A. niger, A. terreus and Cladosporium cladosporioides resisted PCMC at $0.6 \mathrm{~g} / \mathrm{L}$ concentration. 

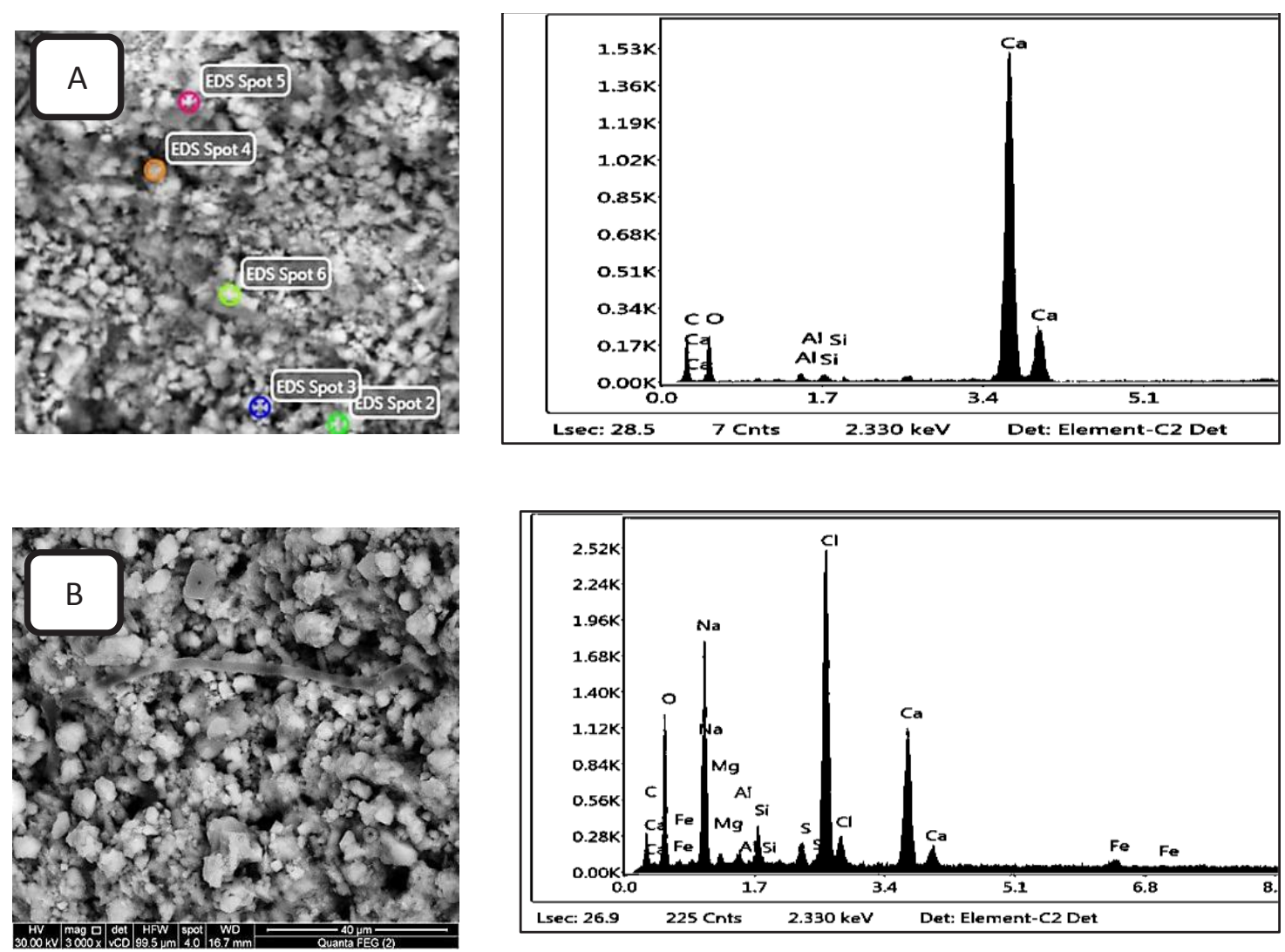

Fig. 4. EDXS microanalysis of (A) Un-infected and (B) Infected limestone.

The minimum inhibitory concentration of cetrimonium was $5 \mathrm{~g} / \mathrm{L}$ for all isolates and $2.5 \mathrm{~g} / \mathrm{L}$ for $55 \%$ of the tested fungal isolates. On the other hand, $2.5 \mathrm{~g} / \mathrm{L}$ of tetra ethyl ammonium bromide was effective against all fungal isolates.

Notably, the minimum inhibitory concentration of essential oils (natural compounds) was greater than that of chemicals, where the minimum inhibitory concentration of cinnamon and clove against all fungal species was $5 \mathrm{~g} / \mathrm{L}$ and $10 \mathrm{~g} / \mathrm{L}$, respectively, and $5 \mathrm{~g} / \mathrm{L}$ of thyme oil was effective against all fungal isolates except for Penicillium rubrum.

Simulation of treatment and conservation of Cladosporium herbarum infected limestone

FTIR analysis of limestones treated with antimicrobial agents revealed that no chemical changes had happened due to application of these active antimicrobial agents. Consequently, they were considered safe substances for the management of deteriorated limestone (Fig. 5)
As for the treatment experiment, the number of viable cells was sharply decreased following treatment, where PCMC $(0.6 \mathrm{~g} / \mathrm{L})$ inhibited all viable cells of infected limestone while cinnamon oil $(1 \mathrm{~g} / \mathrm{L})$ inhibited $99.99 \%$ of them. As for the conservation experiment, PCMC $(0.6 \mathrm{~g} / \mathrm{L})$ inhibited growth by $99.95 \%$, while cinnamon ( $1 \mathrm{~g} / \mathrm{L})$ inhibited growth by $91.4 \%$ (Table 8 ).

\section{Discussion}

Weathering of limestone monuments is not only a result of physical-chemical processes but also a result of microbial deterioration, where fungi are one of the most effective microbiota colonizing stone monuments. The fungal stone flora consists of filamentous fungi and microcolonial fungi. They remain metabolically active even in low nutrient conditions and have high resistance to desiccation, UV radiation and osmotic stress thus being well adapted to growth on external walls at tropical and subtropical environment (Urzi et al., 2000). 


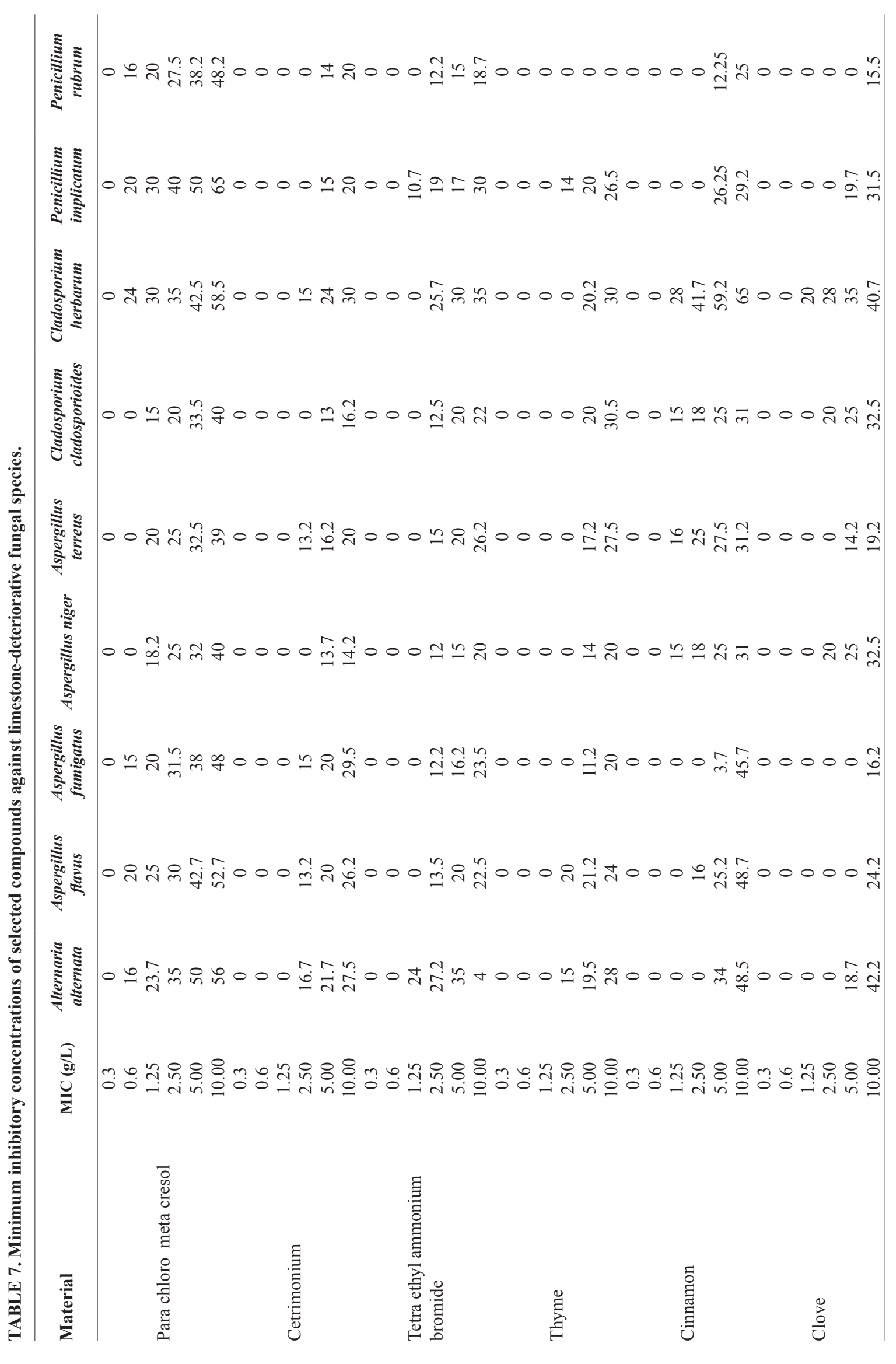



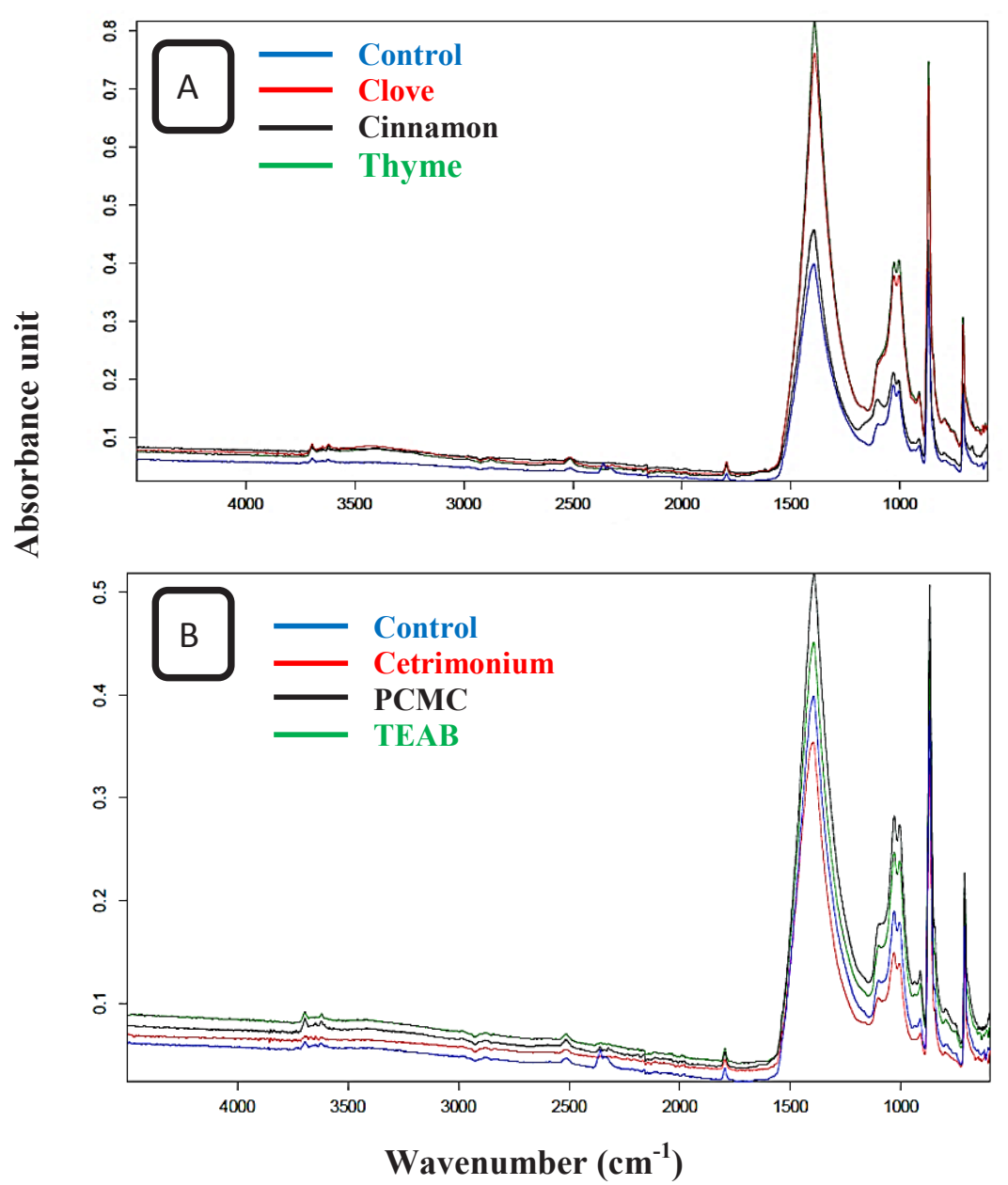

Fig. 5. FTIR analysis of treated and control limestone cubes, (A) Compared charts between untreated control limestone with clove, cinnamon and thyme treated stone, (B) Compared charts between untreated control limestone with cetrimonium, PCMC and TEAB.

TABLE 8. Treatment and conservation of Cladosporium herbarum infected limestones by the MICs of the most active antimicrobial compounds.

\begin{tabular}{lcc}
\hline Limestone sets & Total cell count & Inhibition percentage \\
\hline Control infected limestone (untreated) & $1.4 \times 10^{5}$ & -- \\
Treated limestone by PCMC $(0.6 \mathrm{~g} / \mathrm{L})$ & 0 & 100 \\
Treated limestone by Cinnamon $(1 \mathrm{~g} / \mathrm{L})$ & $10^{3}$ & 99.2 \\
Conserved limestone by PCMC $(0.6 \mathrm{~g} / \mathrm{L})$ & $1.6 \times 10^{3}$ & 98.9 \\
Conserved limestone by Cinnamon $(1 \mathrm{~g} / \mathrm{L})$ & $1.24 \times 10^{4}$ & 91.1 \\
\hline
\end{tabular}

Among the damaging effects of fungi, hyphal penetration of materials form cracks, fissures and crevices, leading to the detachment of crystals, the biochemical acidic metabolites, extra polymeric substances and metal chelating compounds that lead to dissolution and solubilizing of stone minerals (Burford et al., 2003). Moreover, black areas formed due to existence of fungi on stones not only gives the bad appearance of the stone, but also absorbs more light energy which increases physicals stress induced by cycles of expansion/ contraction associated with temperature changes (Sand et al., 2002).

In this study, fifteen fungal species were isolated from different archeological sites 
in Egypt, where Aspergillus was the most predominant genus contaminating all sites and accounting for $46.6 \%$ of the total isolates. Also, Cladosporium was common on stone of art fact, where it was recovered from $85.7 \%$ of the studied sites, while genera of Penicillium, Alternaria and Fusarium occurred in moderate incidence. This fungal profile was similar to those obtained from different monumental sites around the world (Maghazy et al., 2012 and Urzi et al., 2001).

The most fungal contaminated sites were Mosque of Judge Abd El Basset and Senusret I obelisk containing $9.7 \times 10^{4}$ and $9.5 \times 10^{4}$ colony forming units, respectively, followed by Seti I's tomb containing $9 \times 10^{4}$ colony forming units, while the lowest one was at Giza pyramid complex with $8.6 \times 10^{3}$ colony forming units. This may be attributed to the difference in environmental conditions at each site. In addition, Seti I's tomb was exposed to flood waters from rains that entered the lower chamber leading to the fall of large pieces of walls, ceiling and continuous crack formation. Furthermore, the smoke from candles and torches used by early visitors has blackened the walls and left soot deposits on painted reliefs. All these factors contribute together to enhance fungal growth on and also beneath stone surface (Andrew, 2008). In contrast, Giza pyramid complex may have the lowest fungal count due to good ventilation as well as dry and hot weather (Grossi et al., 2006).

Most of the isolated fungi were well adapted to poor nutritive condition. Similar observation was recorded by Grossi et al. (2006) and Suihko et al. (2007) who found that the most stone inhabiting heterotrophic fungi need very low nutrient requirements. In addition, the isolated stone fungal colonizers exhibit high calcium carbonate dissolution ability, acid production, soluble pigment and melanin production as a tool for adaptation to stone as habitats. These mechanisms of adaptation were also recorded by Beata \& Agata (2009). The same results were also observed by Krumbein (1992), who reported that laboratory experiments have shown fungi as the most efficient producers of brown to black stains on rock surfaces.

SEM-EDAX and mechanical characterization of limestone cubes before and after infection at simulation experiment showed extensive colonization of fungal hyphae around stone grains and also their extra polymeric metabolic substances (EPS). This is similar to result obtained by Gadd (2007) and Priester et al. (2007), who found that intrusion of fungal hyphae along the crystal plane by some fungi is known to destabilize the stone texture resulting in its mechanical deterioration. Also elemental analysis (EDXS) of infected area demonstrated a decrease in calcium ratio and increase in oxygen, sodium and chloride ratio. Moreover new elements were detected like sulphur, magnesium and iron indicating new salt formation. Similar results were reported previously as an indicator of biodeterioration (Videla et al., 2000). High amounts of carbon and oxygen were expected for an organic layer and metabolic products which could be organic acids or extracellular polymeric substances (EPS). Also, the percentage of calcium was low, indicating that the limestone substrate was hidden below the organic biofilm layer (Johnston \& Vestal, 1989 and Ferris \& Lowson, 1996).

The present study was also extended to determine the efficiency of some chemical and natural antimicrobial products against monument deterioration. None of the tested compounds caused any changes in the chemical constituents of the stones. All tested chemical substances showed great antifungal activity at concentration reach to $0.03 \%$, while only three of the six tested essential oils showed antifungal activity against tested fungi.

Tetraethyl ammonium bromide and cetrimonium were reported previously to affect the cytoplasmic membrane and cause denaturation of proteins, resulting in leakage of intracellular components and death of microbe (Xuehong \& Jie, 2016), while para, meta chloro cresol was classified as a halo phenolic compound that has both halogen and hydroxyl groups that are generally considered cellular poisons (McDonnell, 2009). Concerning the natural antifungal compounds, cinnamon, clove and thyme were shown to have antifungal activity at very low concentration against almost all rock colonizing fungi which agreed with prior results by Mironescu et al. (2009) and Preeti \& Jain (2014). The exact mechanism of essential oil action is still unclear but some studies suggest that compounds penetrate the cell, where they interfere with cellular metabolism (Guynot et al., 2003; Ooi et al., 2006 and López et al., 2007). 


\section{Conclusion}

These results indicate the ability of the tested compounds to inhibit the fungal growth without affecting mouments' composition.

\section{$\underline{\text { References }}$}

Abd-Elkareem, E.A. and Mohamed, R.M. (2017) Microbial deterioration of limestone of Sultan Hassan mosque, Cairo- Egypt and suggested treatment. International Journal of Chem. Tech. Research, 10(5), 535-552.

Alakomi, H.L., Arrien, N., Gorbushina, A.A., Krumbein, W.E., Maxwell, I., McCullagh, C., Robertson, P., Ross, N., Saarela, M., Valero, J., Vendrell, M. and Young, M.E. (2004) Inhibitors of biofilm damage on mineral materials (BIODAM). Proceedings of $10^{\text {th }}$ Int. Congr. Deterioration and Conservation of Stone. Stockholm. Kwiat-kowski, D. and Löfvendahl, R. ((Ed.), Vol. 1, pp. 399-406.

Andrew, B. (2008) "Pharaoh Seti I's Tomb Bigger Than Thought". National Geographic News, pp. 4-19.

Beata, G. and Agata, C. (2009) The ability of filamentous fungi to produce acids on indoor building materials. Annals of Microbiology, 59(4), 807-813.

Bhatnagar, P. and Jain, S.K. (2014) Antimicrobial activity of plant extract against fungi associated with monument deterioration of Gwalior Fort in India. European Academic Research, 2(5), 6199-6210.

Bordoloi, G.N., Kumarim, B., Guha, A, Bordoloi, M., Yadav, R.N. and Roy, M.K. (2001) Isolation and structure elucidation of a new antifungal and antibacterial antibiotic produced by Streptomyces $\mathrm{sp}$. Biosci Biotechnol Biochem. 65, 1856-1858.

Burford, E.P., Kierans, M. and Gadd, G.M. (2003) Fungal growth in mineral substrata. Geomycology: Mycologist, 17, 98-107.

Caruso, L., Simmons, G. and Wilkens, R. (1985) The physical properties of set of sandstone-part I, the samples. International Journal of Rock Mechanics and Mining Sciences \& Geomechanics Abstracts, 22(6), 381-392.

De Hoog, G.S. and Guarro, J. (1995) "Atlas of Clinical Fungi". Centraalburea Voor Schimmelcultures/ Universtat Rovira I Virgili, Baarn/Reus.
Dominguez-Moñino, I., Diaz-Herraiz, M., Jurado, V., Laiz, L., Miller, A.Z., Santos J.L., Alonso, E. and Saiz-Jimenez, C. (2017) Nature and origin of the violet stains on the walls of a Roman tomb. Sci. Total Environ. 598(15), 889-899.

Eisenman, H.C. and Casadevall, A. (2012) Synthesis and assembly of fungal melanin. Appl. Microbiol. Biotechnol. 93(3), 931-940.

Ettenauer, J. Sterflinger, K. and Piner, G. (2010) Cultivation and molecular monitoring of halophilic microorganisms inhabiting an extreme environment presented by a salt-attacked monument. International Journal of Astrobiology, 9, 59-72.

Evers, H.G. (1929) In: "Staat aus dem Stein Bruckmann", Vol. 2. BruckmannVerlag, Munchen.

Fazio, A.T., Cavicchiolib, A., Penna, D.S.A., Chambergo, F.S. and de Faria, D.L.A. (2015) Towards a better comprehension of biodeterioration in earthen architecture: Study of fungi colonisation on historic wall surfaces. Brazil. J. Cult. Herit. 16, 934-938.

Ferris, F.G. and Lowson, E.A. (1996) Ultrastructure and geochemistry of endolithic microorganisms in limestone of the Niagara Escarpment. Canadian Journal of Microbiology, 43, 211-219.

Fortune, I.S., Aliakmon, H.L., Young, M.E., Gorbushina, A.A., Krumbein, W.E., Maxwell, I., McCullough, C., Robertson, P., Saarela, M., Valero, J. and Ventral, M. (2008) Assessing the suitability of novel biocides for use on historic surfaces. In: "Heritage Microbiology and Science - Microbes, Monuments and Maritime Materials". Springer Vela, Great Britain.

Gadd, G.M. (2007) Geomycology: Biogeochemical transformations of rocks, minerals, metals and radionuclides by fungi, bioweathering and bioremediation. Mycol. Res. 111, 3-49.

Garcia-Valles, M., Urzi, C., De Leo, F., Salamone, P. and Vendrell-Saz, M. (2000) Biological weathering and mineral deposits of the Belevi marble quarry (Ephesus,Turkey). International Biodeterioration \& Biodegradation, 46(3), 221-227.

Grossi, C.M., Brimblecombe, P., Esbert, R.M. and Alonso, F.J. (2006) Color changes in architectural limestones from pollution and cleaning. Color Res. and Application, 32, 320-331. 
Guynot, M.E, Ramos, A.J. Setó, L., Purroy, P., Sanchis, V. and Marín, S. (2003) Antifungal activity of volatile compounds generated by essential oils against fungi commonly causing deterioration of bakery products. Journal of Applied Microbiology, 94, 893-899.

Johnston, C.G. and Vestal, J.R. (1989) Distribution of inorganic species in two Arctic cryptoendolithic microbial communties. Geomicrobiology Journal, 7, 137-153.

Juroczkin, J., Bode, K., Petersen, K. and Krumbein, W.F. (1988) Some physiological characteristics of fungi isolated from sandstone. Proceedings of the $5^{\text {th }}$ International Congress on Deterioration and Conservation of Stone, Poland, pp. 21-25.

Klich, M.A. (2001) Identification of common Aspergillus species. New Orleans, LA: United States Department of Agricultural Research Service, Southern Regional Research Center.

Kordali, S., Kotan, R., Mavi, A., Cakir, A., Ala, A. and Yildirim, A. (2005) Determination of the chemical composition and antioxidant activity of the essential oil of Artemisia dracunculus and of the antifungal and antibacterial activities of Turkish Artemisia absinthium, A. dracunculus, Artemisia santonicum, and Artemisia spicigera essential oils. J. Agric. Food Chem. 53(24), 9452-9458.

Krumbein, W.E. (1992) Color changes of building stones and their direct and indirect biological causes. In: J. Delgado Rodriguez, F. Henriques and F. Telmo Jeremias (Ed.), Proceedings of the $7^{\text {th }}$ International Congress on Deterioration and Conservation of Stone, Lisbon, pp. 443-452

Liaud, N., Ginies, C., Navarro, D., Fabre, N., Crapart, S. and Sigoillot, J.C. (2014) Exploring fungal biodiversity: organic acid production by 66 strains of filamentous fungi. Fungal Biol. Biotechnol. 1, 1-10.

López, P., Sánchez, C., Batlle, R. and Nerín, C. (2007) Development of flexible antimicrobial films using essential oils as active agents. J. Agric. Food Chem. 55(21), 8814-8824.

Ma, Y., Zhang, He Du, Ye., Tian, T., Xiang T., Xiande, L., Fasi, W., Lizhe, A., Wanfu, W., Ji-Dong, G. and Huyuan, F. (2015) The community distribution of bacteria and fungi on ancient wall paintings of the Mogao Grottoes. Sci. Rep. 5, 7752.
Maghazy, S.M.N., Abdel-Zaher, H.M.A. and El-Gendy, Z.Kh. (2012) Indoor aeromycobiota of monumental sites in Minia Governorate. Journal of Basic \& Applied Mycology, 3, 49-59.

McDonnell, G. (2009) Sterilization and Disinfection. "Encyclopedia of Microbiology", ( $3^{\text {rd }}$ ed.), pp. 529548.

Mironescu, M., Georgescu, C. and Oprean, L. (2009) Comparative sporicidal effects of volatile oils. Journal of Agroalimentary Processes and Technologies, 15(3), 361-365.

Mourad, Z., Dounia, M., Soumya, E., Adnane, R. and Saad Ibnsouda, K. (2011) Antifungal activity of five plant essential oils against wood decay fungi isolated from an old house at the Medina of Fez. International Research Journal of Microbiology, 2(3), 104-108.

Ooi, L.S., Li, Y., Kam, S.L., Wang, H., Wong, E.Y. and Ooi, V.E. (2006) Antimicrobial activities of cinnamon oil and cinnamaldehyde from the Chinese medicinal herb Cinnamomum cassia Blume. Am. J. Chin. Med. 34(3), 511-22.

Paris, F., Bonnaud, P., Ranger, J., Robert, M. and Lapeyrie, F. (1995) Weathering of ammoniumor calcium-saturated 2:1 phyllosilicates by ectomycorrhizal fungi in vitro. Soil Biol. Biochem. 27, 1237-1244.

Pitt, J.I. (2000) "A Laboratory Guide to Common Penicillium Species". North Ride, NSW: Food Science Australia.

Preeti, B. and Jain, S.K. (2014) Alternative control techniques against fungal colonization for preserving monument deterioration. International Journal of Current Microbiology and Applied Science, 3(7), 40-43.

Priester, J.H., Horst, A.M., Van De Werfhorst, L.C., Saleta, J.L., Mertes, L.A.K., and Holden, P.A. (2007) Enhanced visualization of microbial biofilms by staining and environmental scanning electron microscopy. J. Microbiol. Meth. 68(3), 577-587.

Saiz-Jimenez, C. (1995) Microbial melanins in stone monuments. Science of the Total Environment, 167(1-3), 273-300.

Sand, W., Jozsa. P.G. and Mansch, R. (2002) Weathering, 
Microbiology. In: "Environmental Microbiology", Britton, G. (Ed.), Vol. 6, pp. 3364-3375.

Sarah, E., Ryan, W. H. and Mark, A.S. (2013) Isolation and characterization of halotolerant soil fungi from the Great Salt Plains of Oklahoma. Mycol. 34(4), 329-341.

Scott, W. (1969) "Standard Method of Chemical Analysis", $5^{\text {th }}$ ed., Vol. $1 \& 2$.

Strzelczyk, A.B. (2004) Observation on aesthetic and structural changes induced in Polish historic objects by microorganisms. International Biodeterioration \& Biodegradation, 53(3), 151-156.

Suihko, L.M., Alakomi, L.H., Gorbushina, A.A., Fortune, I., Ma rquard and Saarela, M. (2007) Characterization of aerobic bacterial and fungal microbiota on surfaces of historic Scottish monuments. Syst. Appl. Microbiol. 30, 494-508.

Urzi, C., de Leo, F., de How, S. and Sterflinger, K. (2000) Recent advances in the molecular biology and ecophysiology of meristematic stone-inhabiting fungi. In: "Of Microbes and Art. The Role of Microbial Communities in the Degradation and Protection of Cultural Heritage", O. Ciferri, P. Tiano and G. Mastromei (Ed.), pp.3-21. Kluwer Academic/Plenum Publisher, New York.

Urzi, C., De-Leo, F., Paola, S. and Criseo, G. (2001)
Air-borne fungal spores colonizing marbles exposed in the terrace of Messina Museum, Sicily. Aerobiologia, 17(1), 11-17.

Urzì, C., De Leo, F., Donato, P. and La Cono, V. (2003) Study of microbial communities colonizing monument surfaces using nondestructive and destructive sampling methods. In: "Art, Biology and Conservation: Biodeterioration of Works of Art", R.J. Koestler, Koestler, V.R., Charola, A.E. and Nieto-Fernandez, F.E. (Ed.), pp. 316-327. The Metropolitan Museum of Art, New York.

Videla, H.A., Guiamet, P.S. and Gomez de Saravia, S. (2000) Biodeterioration of Mayan archaeological sites in the Yucatan Peninsula, Mexico. Int. Biodeterior. Biodegrad. 46, 335-341.

Xuehong, R. and Jie, L. (2016) Smart anti-microbial composite coatings for textiles and plastics. A volume in Wood head Publishing Series in Composites Science and Engineering, (9), pp. 235 259.

Zarina, S. and Parwez, Q. (2013) Screening and isolation of organic acid producers from samples of diverse habitats. Int. J. Curr. Microbiol. App. Sci. 2 (9), 39-44. 
التوصيف والتحكم بالتدهور الفطري للحجر الجيري القديم في مواقع مختلفة بمصر

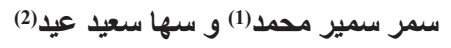

(1) قسم الميكروبيولوجى - كلية العلوم - جامعة عين شمس - القاهرة - مصر و (2) زز ارة الاثار - مركز البحوث

وحفظ الاثار - القاهرة - مصر . كلى

تلعب الفطريات دور مخادع في التدهور الحيوي للأثار مما يؤدي إلى فقدانها. ولكي نحافظ على هذه الأثار،

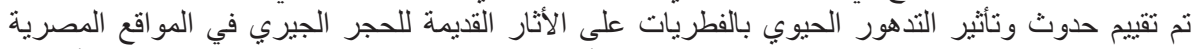

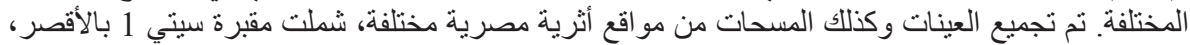

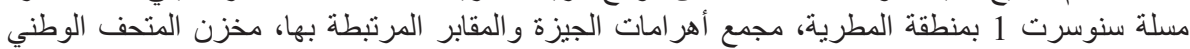

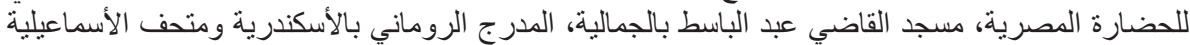

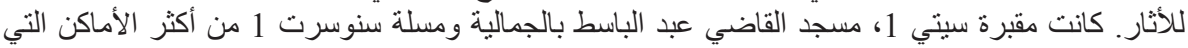

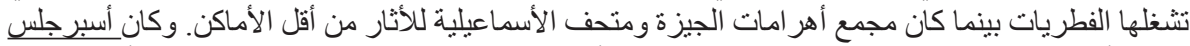

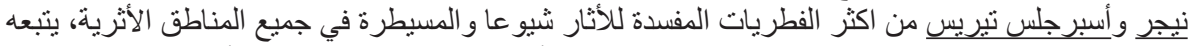

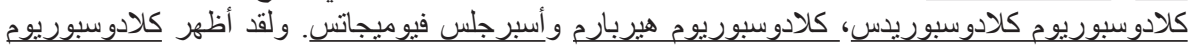

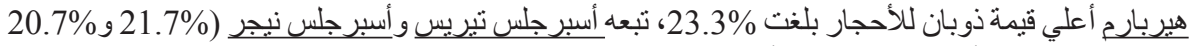

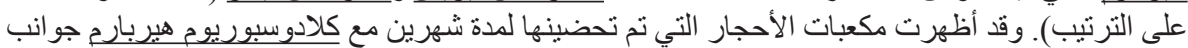

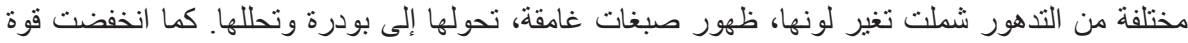
الضغط ومسامية الحجر بنسبة 27.7\% و 25.7\% على الترتيب. بالنسبة لمضادات الميكروبات الإصطناعية

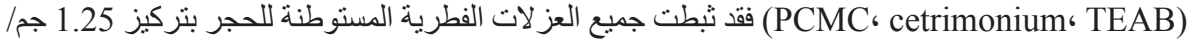

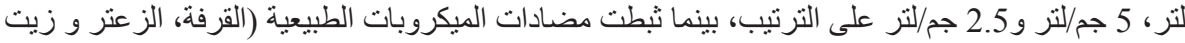

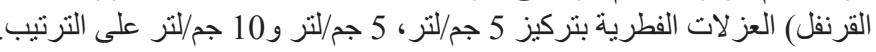

